\title{
In vitro evaluation of cryopreserved bovine sperm and its relation to field fertility in fixed-time artificial insemination
}

\author{
Denise S. Okano $^{1}$ | Jurandy M. Penitente-Filho ${ }^{1}$ (D) | Victor E. Gomez León ${ }^{1}$ | \\ Paula P. Maitan ${ }^{1}$ (D) | Camila O. Silveira ${ }^{1}$ | Bruna Waddington ${ }^{1}$ | \\ Edgar A. Díaz-Miranda ${ }^{1}$ | Eduardo P. da Costa ${ }^{1}$ | Simone E. F. Guimarães ${ }^{2}$ | \\ José D. Guimarães ${ }^{1}$
}

${ }^{1}$ Department of Veterinary, Universidade Federal de Viçosa, Viçosa, Brazil

${ }^{2}$ Department of Animal

Science, Universidade Federal de Viçosa, Viçosa, Brazil

\section{Correspondence}

Denise S. Okano, Department of Veterinary, Universidade Federal de Viçosa, Viçosa, Brazil.

Email: deniseokano@gmail.com

\section{Contents}

This study aimed to assess characteristics of bovine cryopreserved sperm and evaluate its relation to field fertility in fixed-time artificial insemination (FTAI). Semen samples of 16 bulls were used to inseminate 811 Nellore cows, and four of these bulls were also used to inseminate 101 Nellore heifers. Samples of the same ejaculate used for FTAI from each bull were analysed in the laboratory after thawing. Sperm motility and vigour were subjectively assessed by light microscope, and integrity of the plasma and acrosome membranes, and $\mathrm{H}_{2} \mathrm{O}_{2}$ production were evaluated by flow cytometer. Relation among sperm characteristics and pregnancy rate of cows and heifers were evaluated by univariate and multivariate logistic regression. Subjective sperm motility and vigour did not affect the probability of pregnancy in cows or heifers. In univariate analysis for pregnancy in cows, sperm traits related to acrosome injury positively affected probability of pregnancy mainly when associated with plasma membrane integrity; $\mathrm{H}_{2} \mathrm{O}_{2}$ production seems to be less important than plasma membrane integrity in affecting probability of pregnancy. In multivariate analysis, sperm traits related to injured acrosome positively affected probability of cow and heifer pregnancies while intact acrosome was negatively related to cow pregnancy. Intact plasma membrane and high $\mathrm{H}_{2} \mathrm{O}_{2}$ production were positively related to cow pregnancy but negatively related to heifer pregnancy. Results suggest that a capacitation-like status of the acrosome may benefit probability of pregnancy in cows.

KEYWORDS

cattle, flow cytometer, semen fertility

\section{1 | INTRODUCTION}

The sperm cell becomes infertile when one or more of its biochemical or morphological factors are affected (Siqueira et al., 2007), and by this, the evaluation of only one of these points does not guarantee the normal condition of the other. Therefore, a combination of several characteristics in a multifactorial analysis is more appropriate for the diagnosis of the functionality and integrity of the sperm cell (Tartaglione \& Ritta, 2004).
In semen production centres, the main parameters that are usually used to assess bull seminal quality are sperm motility and morphology. Although being a minimum standard of semen quality, these analyses also attend for selection of semen donors.

Subjective sperm motility assessment has been statistically related to fertility, even for post-thawed semen in bulls (Rodríguez-Martínez, 2003). However, this parameter has shown to be an ineffective predictor for semen fertility in commercial artificial insemination (Siqueira et al., 2007); even kinematic analyses using CASA (computer-assisted 
sperm analyser) have shown inconstant correlations between motility patterns and field fertility (Bailey, Robertson, \& Buhr, 1994; Januskauskas, Johannisson, \& Rodríguez-Martínez, 2001, 2003; Rodríguez-Martínez, 2013; Zhang, Larsson, Lundeheim, \& RodríguezMartínez, 1998). Therefore, alternative methods for semen evaluation have been developed to enhance routine tests (Rodríguez-Martínez, 2013; Taş, Bacinoglu, Cirit, Ozdaş, \& Ak, 2007; Verberckmoes, Soom, Depauw, Dewulf, \& Kruif, 2002). Even though these methods have been proved to be useful for in vitro sperm evaluation, they still have limited ability to predict field fertility (Morado, Pereyra, Breininger, Sara, \& Cetica, 2015). Thereby, simultaneous measurement of multiple sperm traits could improve the estimation of sperm fertility (Gadea, 2005; Gillan, Kroetsch, Maxwell, \& Evans, 2008; Graham, 2001). In this context, flow cytometer analysis appears as a useful tool to evaluate several sperm characteristics and relate them to field fertility (Oliveira, Arruda, Andrade, Celeghini et al., 2012).

Therefore, this study aimed to evaluate the effects of sperm characteristics, such as subjective sperm motility and vigour, acrosome and plasma membrane integrity, and $\mathrm{H}_{2} \mathrm{O}_{2}$ production, on field fertility in a fixed-time artificial insemination (FTAI) programme of Nellore cows and heifers.

\section{2 | MATERIALS AND METHODS}

\subsection{Ethics}

This study followed the Standards of Conduct for the Use of Animals in Research and Education approved by the Ethics Committee for Animal Use of the Universidade Federal de Viçosa, proc. n. 07/2015.

\subsection{Local and animals}

Lactating Nellore cows $(n=811)$ and heifers $(n=101)$ were located in Carlos Chagas/MG, Brazil, 17.8511 ${ }^{\circ}$ South and $40.7171^{\circ}$ West. Cows aged between 1,140 and 4,452 days, weighted between 400 and $450 \mathrm{~kg}$ with body condition score (BCS) ranging from 2 to 3 (scale of 1-5); heifers aged between 712 and 1,142 days, weighted between 350 and $400 \mathrm{~kg}$ with BCS ranging from 2.5 to 3 .

Artificial inseminations were performed during the 2014/2015 breeding season (from November 2014 to February 2015). Females were kept in Urochloa decumbens pasture, with ad libitum mineral salt and water. Laboratorial evaluations were carried out in Laboratory of Animal Andrology of the Department of Veterinary and Microscopy and Microanalysis Sector, in the Universidade Federal de Viçosa, Brazil.

\section{3 | Fixed-time artificial insemination}

All females were synchronized for FTAI by following protocol (TECNOPEC 2008, available from https://www.abspecplan.com. br/upload/library/Manual_IATF_Bovinos.pdf): day 0: insertion of progesterone device (Primer ${ }^{\circledR}$, Tecnopec) and administration, i.m., of $2 \mathrm{ml}$ estradiol benzoate (RIC-BE ${ }^{\circledR}$, Tecnopec); day 8: removal of progesterone device and administration, i.m., of $1 \mathrm{ml}$ estradiol benzoate, $2 \mathrm{ml} \mathrm{PGF}{ }_{2 \alpha}$ (Prolise ${ }^{\circledR}$, Tecnopec) and $0.5 \mathrm{ml}$ porcine follicle-stimulating hormone (Folltropin ${ }^{\circledR}$, Tecnopec); and day 10: artificial insemination $60 \mathrm{hr}$ after progesterone device removal. Pregnancy diagnosis was performed by ultrasound 30 days after artificial insemination.

\subsection{Semen samples}

For semen evaluations, frozen semen samples (straws with $30 \times 10^{6}$ sperm) were used. Bulls that were used to inseminate at least 20 cows and at least 17 heifers were kept in data set. After data curation, 16 of the bulls (nine Nellore, four Tropical Montana composite, one Senepol, one Holstein and one Red Angus) that were used to inseminate the cows and four of the bulls (two Nellore, one Tropical Montana composite and one Senepol) that were used to inseminate heifers were included in analyses.

\section{5 | Sperm motility and vigour}

Immediately after thawing $\left(37^{\circ} \mathrm{C}\right.$ for $\left.20-30 \mathrm{~s}\right)$, a droplet of semen $(10 \mu \mathrm{l})$ was placed in a pre-heated $\left(37^{\circ} \mathrm{C}\right)$ slide glass and covered by a coverslip and lead to an optical microscope at 400× magnificence (CBRA, 2013). Sperm motility (0\%-100\%) and sperm vigour (score from 0 to 5 ) were subjectively assessed by the same technician in at least four fields in each sample, and the results were expressed in average of the fields.

\subsection{Flow cytometer analyses}

All analyses were performed in a BD FACSVerse ${ }^{\mathrm{TM}}$ (BectonDickinson ${ }^{\circledR}$, Sunnyvale, CA, USA) flow cytometer. For flow cytometer calibration, semen samples from a fertile bull were diluted in PBS (phosphate-buffered saline) at $5 \times 10^{6} \mathrm{sperm} / \mathrm{ml}$. The non-spermatic particles (debris) and particles with similar dispersion to sperm but without sufficient DNA were excluded.

Samples were first analysed without dyes, and then, the size $x$ granularity scale was determined to specify where the sperm population was located. Sequentially, sperm and debris were sorted based on the sperm fluorescent characteristics (Ricci et al., 2002) through the use of the propidium iodide (PI) probe, which stains only structures with DNA. Tests were repeated until the appropriate selection of the expected population, and then, the best fit (compensation) obtained for each probe was determined as standard.

\section{7 | Evaluation of acrosome and plasma membrane integrity}

Acrosome and plasma membrane were evaluated according to a modified protocol described by Oliveira, Arruda, Andrade, Santos et al. (2012). A $150 \mu \mathrm{L}$ aliquot of semen diluted in DPBS (Dulbecco's phosphate-buffered saline) $\left(5 \times 10^{6} \mathrm{sperm} / \mathrm{mL}\right)$ was incubated with $10 \mu \mathrm{L}$ of Pisum sativum agglutinin conjugated to fluorescein isothiocyanate (FITC-PSA; $100 \mu \mathrm{g} / \mathrm{mL}$ ) and $3 \mu \mathrm{L}$ of propidium iodide (PI; 
TAB LE 1 Pregnancy rates in Nellore cows and heifers submitted to FTAI (fixed-time artificial insemination) according to the bulls

\begin{tabular}{|c|c|c|}
\hline Bull & $\begin{array}{l}\text { Pregnancy rate in cows, \% } \\
\left(\mathrm{n}^{\mathrm{a}}\right)\end{array}$ & $\begin{array}{l}\text { Pregnancy rate in } \\
\text { heifers, \% }\left(\mathrm{n}^{\mathrm{a}}\right)\end{array}$ \\
\hline 5 & $68.8(32)$ & - \\
\hline 6 & $65.9(41)$ & - \\
\hline 7 & 64.5 (31) & 82.4 (17) \\
\hline 10 & $64.6(130)$ & - \\
\hline 12 & $65.9(41)$ & - \\
\hline 13 & $50.0(46)$ & 63.2 (19) \\
\hline 16 & $60.0(30)$ & - \\
\hline 18 & $55.6(63)$ & - \\
\hline 30 & $61.9(97)$ & $79.2(24)$ \\
\hline 31 & $40.0(20)$ & - \\
\hline 33 & 33.6 (107) & - \\
\hline 34 & $48.3(29)$ & - \\
\hline 35 & $58.9(56)$ & - \\
\hline 39 & $75.0(20)$ & - \\
\hline 45 & $45.0(20)$ & - \\
\hline 47 & $56.3(48)$ & $53.7(41)$ \\
\hline
\end{tabular}

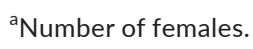

$0.5 \mathrm{mg} / \mathrm{ml}$ ) at $37^{\circ} \mathrm{C}$ for $10 \mathrm{~min}$. Then, $150 \mu \mathrm{L}$ of DPBS was added and the sample was assessed. In each sample, 10,000 cells were analysed (approximately 200 sperm cells/second) in a $488 \mathrm{~nm}$ laser excitation. The purpose of these probes was to stain the cells with damaged plasma membranes (PI positive) and those that had injured acrosome (FITC-PSA positive).

Two-dimensional dot-plot graphics of FITC-PSA versus PI fluorescence were created. Each quadrant represented one of the following sperm subpopulations: (1) sperm with intact plasma and acrosome membranes (PI -, FITC-PSA -); (2) sperm with intact plasma membrane and damaged acrosome membrane (PI -, FITC-PSA +); (3) sperm with damaged plasma membrane and intact acrosome membrane (PI +, FITC-PSA -); and (4) sperm with damaged plasma and acrosome membranes (PI +, FITC-PSA +).

\subsection{Evaluation of $\mathrm{H} 2 \mathrm{O} 2$ production (DCFDA/PI)}

Production of $\mathrm{H}_{2} \mathrm{O}_{2}$ was assessed according to the protocol proposed by Macías-García et al. (2012). A $150 \mu \mathrm{L}$ aliquot of semen was diluted in DPBS $\left(5 \times 10^{6} \mathrm{sperm} / \mathrm{mL}\right)$ at $37^{\circ} \mathrm{C}$ and stained with 0.5 $\mu \mathrm{L}$ 2',7'-dichlorofluorescin diacetate (DCFDA; $1 \mathrm{mg} / \mathrm{ml}$ of $2 \mathrm{mM}$ dimethyl sulphoxide) for $30 \mathrm{~min}$; then, from this solution, $150 \mu \mathrm{L}$ was collected, stained with $3 \mu \mathrm{L} \mathrm{PI}$ and incubated for $5 \mathrm{~min}$. Finally, 150 $\mu \mathrm{L}$ DPBS was added and the sample was assessed.

Four different cell populations were observed: $\mathrm{PI}(+)$ and DCFDA (-), sperm cells with damaged plasma membrane and low intracellular $\mathrm{H}_{2} \mathrm{O}_{2}$ production; PI (+) and DCFDA (+), sperm cells with damaged plasma membrane and high intracellular $\mathrm{H}_{2} \mathrm{O}_{2}$ production; PI (-) and DCFDA (+), sperm cells with normal plasma membrane and high intracellular $\mathrm{H}_{2} \mathrm{O}_{2}$ production; and $\mathrm{PI}(-)$ and DCFDA (-), sperm cells with intact plasma membrane and low intracellular $\mathrm{H}_{2} \mathrm{O}_{2}$ production.

\section{9 | Statistical analysis}

Data analysis was performed in the Statistical Analysis System (SAS, 2002). For pregnancy rates, data were submitted to chi-square test (Freq Procedure) and rates were considered different when $p<0.05$. Percentage data from flow cytometer analysis were submitted to angular transformation $\left(Y_{\prime}=\arcsin (\sqrt{Y})\right)$, and then, a univariate logistic regression (logistic procedure) was performed in order to evaluate the influence of each sperm trait on probability of pregnancy of cows and heifers; variables were considered significant when $p<0.10$. Sperm traits and age of females were also evaluated by multivariate logistic regression, and only explanatory variables that were significant at $p<0.25$ by stepwise selection were kept in final model. The association of predicted probabilities and observed responses was evaluated by the area under the receiver operator characteristic (ROC) curve (c) (Hosmer \& Lemeshow, 2000).

\section{3 | RESULTS}

A total of 912 females were inseminated resulting in 525 pregnancies. The pregnancy rate was similar $(p=0.059)$ between heifers (66.3\%) and cows (56.5\%). The overall pregnancy rate per bull for all females ranged from $33.6 \%$ to $75.0 \%$; there was significant effect of bull for cow ( $p=0.0003$ ) but not for heifer $(p=0.080)$ pregnancy (Table 1). Sperm parameters are shown in Table 2.

Results of analysis of maximum-likelihood estimates from the univariate logistic regression to predict probability of pregnancy in cows and heifers are in Tables 3 and 4, respectively. For both female categories, subjective sperm motility and vigour showed no significant effect on the probability of pregnancy. For pregnancy in cows, sperm traits related to acrosome damage positively affected the probability of pregnancy mainly when associated with plasma membrane integrity (higher $\beta_{1}$ value). Regarding the $\mathrm{H}_{2} \mathrm{O}_{2}$ production, it seems to have less importance than plasma membrane integrity in affecting the probability of cow pregnancy. For heifers, damaged plasma membrane and low $\mathrm{H}_{2} \mathrm{O}_{2}$ production were positively related to probability of pregnancy. High $\mathrm{H}_{2} \mathrm{O}_{2}$ production was negatively related to the pregnancy in heifers even when associated with intact plasma membrane.

For multivariate logistic regression, four variables were kept in the final model for pregnancy in cows and two variables for pregnancy in heifers (Table 5). For cows and heifers, sperm traits related to damaged acrosome positively affected the probability of pregnancy while intact acrosome was negatively related to cow pregnancy. High $\mathrm{H}_{2} \mathrm{O}_{2}$ production and intact plasma membrane were positively related to cow pregnancy but negatively related to heifer pregnancy. Age of female was positively related to cow pregnancy. 
TAB LE 2 Subjective sperm motility (\%), sperm vigour (0-5) and flow cytometer parameters (\%) from 16 bulls used for fixed-time artificial insemination of Nellore cows and heifers

\begin{tabular}{|lrl}
\hline Variables & Mean \pm SEM & Range $^{\mathrm{a}}$ \\
\hline Sperm motility & $58.44 \pm 3.56$ & $30.0-75.0$ \\
\hline $\begin{array}{l}\text { Sperm vigour (O-5) } \\
\text { Damaged plasma membrane and intact } \\
\text { acrosome membrane }\end{array}$ & $2.63 \pm 0.13$ & $2.0-3.0$ \\
\hline $\begin{array}{l}\text { Damaged plasma and acrosome } \\
\text { membranes }\end{array}$ & $7.55 \pm 1.50$ & $2.5-21.6$ \\
\hline $\begin{array}{l}\text { Intact plasma membrane and damaged } \\
\text { acrosome membrane }\end{array}$ & $2.36 \pm 0.51$ & $0.03-17.3$ \\
\hline $\begin{array}{l}\text { Intact plasma and acrosome } \\
\text { membranes }\end{array}$ & $81.84 \pm 2.18$ & $0.003-6.4$ \\
\hline $\begin{array}{l}\text { Damaged plasma membrane and low } \\
\mathrm{H}_{2} \mathrm{O}_{2} \text { production }\end{array}$ & $3.07 \pm 0.99$ & $67.4-95.1$ \\
\hline $\begin{array}{l}\text { Damaged plasma membrane and high } \\
\mathrm{H}_{2} \mathrm{O}_{2} \text { production }\end{array}$ & $21.59 \pm 4.97$ & $0.2-16.3$ \\
\hline $\begin{array}{l}\text { Normal plasma membrane and high } \\
\mathrm{H}_{2} \mathrm{O}_{2} \text { production }\end{array}$ & $5.52 \pm 1.93$ & $0.6-75.4$ \\
\hline $\begin{array}{l}\text { Normal plasma membrane and low } \\
\mathrm{H}_{2} \mathrm{O}_{2} \text { production }\end{array}$ & $69.82 \pm 5.49$ & $0.5-29.0$ \\
\hline
\end{tabular}

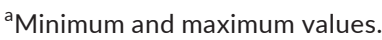

TABLE 3 Analysis of maximumlikelihood estimates and area under receiver operator characteristic (ROC) curve from the univariate logistic regression used to predict probability of pregnancy in Nellore cows

\begin{tabular}{|c|c|c|c|c|}
\hline Variable & $\beta_{0}$ & $\beta_{1}$ & $p$-Value & c \\
\hline Sperm motility & 0.4014 & -0.1574 & 0.7836 & 0.508 \\
\hline Sperm vigour & 0.3024 & 0.0822 & 0.3202 & 0.515 \\
\hline $\begin{array}{l}\text { Damaged plasma membrane and intact } \\
\text { acrosome membrane }\end{array}$ & 0.7194 & -1.8138 & 0.0632 & 0.548 \\
\hline $\begin{array}{l}\text { Damaged plasma and acrosome } \\
\text { membranes }\end{array}$ & -0.1515 & 1.8126 & 0.0005 & 0.570 \\
\hline $\begin{array}{l}\text { Intact plasma membrane and damaged } \\
\text { acrosome membrane }\end{array}$ & -0.1319 & 3.0823 & 0.0008 & 0.566 \\
\hline Intact plasma and acrosome membranes & 1.2791 & -0.8638 & 0.1177 & 0.519 \\
\hline $\begin{array}{l}\text { Damaged plasma membrane and low } \\
\mathrm{H}_{2} \mathrm{O}_{2} \text { production }\end{array}$ & 0.6036 & -2.3845 & 0.0116 & 0.537 \\
\hline $\begin{array}{l}\text { Damaged plasma membrane and high } \\
\mathrm{H}_{2} \mathrm{O}_{2} \text { production }\end{array}$ & 0.5280 & -0.6124 & 0.0316 & 0.547 \\
\hline $\begin{array}{l}\text { Normal plasma membrane and high } \\
\mathrm{H}_{2} \mathrm{O}_{2} \text { production }\end{array}$ & 0.0870 & 0.9647 & 0.0960 & 0.571 \\
\hline $\begin{array}{l}\text { Normal plasma membrane and low } \mathrm{H}_{2} \mathrm{O}_{2} \\
\text { production }\end{array}$ & -0.3467 & 0.5878 & 0.0423 & 0.546 \\
\hline Age of female (days) & -0.2293 & 0.000213 & 0.0092 & 0.557 \\
\hline
\end{tabular}

Note. $\beta_{0}$ (intercept) and $\beta_{1}$ are the parameter estimates of the logistic regression. $c$, area under ROC curve.

Based on estimates shown in Table 5, the probability of pregnancy for each bull was calculated and compared to the observed pregnancy rate of cows (Figure 1) and heifers (Figure 2). For cows, three bulls presented a difference between predicted and observed pregnancy rates higher than $20 \%$. For heifer pregnancy, all bulls showed predicted rates similar to observed values.

\section{4 | DISCUSSION}

Several authors have showed a large variation in pregnancy rates for bulls that are used in FTAI. These variations have also been demonstrated in vitro for cleavage and blastocyst rates, in vitro capacitation and acrosome integrity (Marquant-Le Guienne, Humblot, Thibier, \& Thibault, 1990; Meneghetti, Sá Filho, Peres, Lamb, \& Vasconcelos, 2009; Rodríguez-Martínez, Larsson, 


\begin{tabular}{|c|c|c|c|c|}
\hline Variable & $\beta_{0}$ & $\beta_{1}$ & $p$-Value & c \\
\hline Sperm motility & 0.4241 & 0.2953 & 0.9170 & 0.489 \\
\hline Sperm vigour & 0.7455 & 0.2100 & 0.3531 & 0.547 \\
\hline $\begin{array}{l}\text { Damaged plasma membrane and intact } \\
\text { acrosome membrane }\end{array}$ & 2.0189 & -4.3338 & 0.1220 & 0.615 \\
\hline $\begin{array}{l}\text { Damaged plasma and acrosome } \\
\text { membranes }\end{array}$ & -0.0084 & 2.2814 & 0.2269 & 0.615 \\
\hline $\begin{array}{l}\text { Intact plasma membrane and damaged } \\
\text { acrosome membrane }\end{array}$ & 0.5942 & 0.4042 & 0.8855 & 0.461 \\
\hline Intact plasma and acrosome membranes & 0.9418 & -0.2469 & 0.8811 & 0.505 \\
\hline $\begin{array}{l}\text { Damaged plasma membrane and low } \\
\mathrm{H}_{2} \mathrm{O}_{2} \text { production }\end{array}$ & 0.0063 & 6.5106 & 0.0812 & 0.616 \\
\hline $\begin{array}{l}\text { Damaged plasma membrane and high } \\
\mathrm{H}_{2} \mathrm{O}_{2} \text { production }\end{array}$ & -0.1403 & 1.2770 & 0.2784 & 0.505 \\
\hline $\begin{array}{l}\text { Normal plasma membrane and high } \mathrm{H}_{2} \mathrm{O}_{2} \\
\text { production }\end{array}$ & 1.3242 & -2.0763 & 0.0265 & 0.616 \\
\hline $\begin{array}{l}\text { Normal plasma membrane and low } \mathrm{H}_{2} \mathrm{O}_{2} \\
\text { production }\end{array}$ & 0.4963 & 0.2355 & 0.7941 & 0.495 \\
\hline Age of female (days) & -0.6224 & 0.00162 & 0.6557 & 0.518 \\
\hline
\end{tabular}

TABLE 4 Analysis of maximumlikelihood estimates and area under receiver operator characteristic (ROC) curve from the univariate logistic regression used to predict probability of pregnancy in Nellore heifers

Note. $\beta_{0}$ (intercept) and $\beta_{1}$ are the parameter estimates of the logistic regression. $c$, area under ROC curve.

\begin{tabular}{lccc}
\hline Parameter & Estimate & $p$-Value & $c$ \\
\hline In cows & & & \\
\hline $\begin{array}{l}\text { Intercept } \\
\text { Damaged plasma membrane and intact } \\
\text { acrosome membrane }\end{array}$ & -0.1876 & 0.5896 & 0.592 \\
$\begin{array}{l}\text { Damaged plasma and acrosome } \\
\text { membranes }\end{array}$ & 1.7848 & 0.0211 & \\
$\begin{array}{l}\text { Normal plasma membrane and high } \mathrm{H}_{2} \mathrm{O}_{2} \\
\text { production }\end{array}$ & 0.9137 & 0.1299 & \\
$\quad$ Age of female (days) & 0.000207 & 0.0126 & \\
\hline $\begin{array}{l}\text { In heifers } \\
\text { Intercept }\end{array}$ & 0.5140 & 0.4366 \\
$\quad \begin{array}{l}\text { Normal plasma membrane and high } \mathrm{H}_{2} \mathrm{O}_{2} \\
\text { production }\end{array}$ & -2.2243 & 0.0204 & \\
$\quad \begin{array}{l}\text { Damaged plasma and acrosome } \\
\text { membranes }\end{array}$ & 2.8793 & 0.1576 & \\
\hline
\end{tabular}

TABLE 5 Analysis of maximumlikelihood estimates and area under receiver operator characteristic $(\mathrm{ROC})$ curve of the multivariate logistic regression used to predict probability of pregnancy in Nellore cows and heifers

Note. c, area under ROC curve.

Zhang, \& Söderquist, 1997; Sudano et al., 2011; Wei \& Fukui, 1999).

Sperm motility is one of the most important characteristics associated with fertilizing ability being the main analysis used by the centres of artificial insemination (Crespilho et al., 2006; OldsClarke, 1996). Nevertheless, in this experiment, univariate and multivariate logistic regression showed that subjective sperm motility and vigour did not influence the probability of pregnancy. The absence of relation between CASA-analysed or subjective sperm motility and fertility was previously described (Bailey et al., 1994; Januskauskas et al., 1999; Oliveira, Arruda, Andrade, Celeghini et al., 2012; Stålhammar, Janson, \& Philipsson, 1994), although positive correlation was also reported (Gillan et al., 2008; Li, Kalo, Zeron, \& Roth, 2014). Therefore, findings of this study may suggest that sperm motility itself is not a suitable parameter to predict semen fertility, and it seems clear that other sperm characteristics should be considered to evaluate semen fertility potential. It is important to highlight that sperm motility evaluation should consider the sperm concentration (Mohanty et al., 2018). In this study, subjective sperm motility ranged from $30 \%$ to $75 \%$, considering straws with $30 \times 10^{6}$ sperm, even the lowest sperm motility represented at least $9 \times 10^{6}$ of viable sperm cells which is considered as a satisfactory inseminating 
FIGURE 1 Observed and predicted pregnancy rates of bulls used in fixed-time artificial insemination of Nellore cows. Predicted values were estimated from the general formula $P=\frac{e^{\left(\beta_{0}+\ldots+\beta_{p} x_{p}\right)}}{1+e^{\left(\beta_{0}+\ldots+\beta_{p} x_{p}\right)}}$, where $\beta_{0}$, intercept; $\beta_{\mathrm{p}}$, coefficients estimated by logistic regression for each parameter; and $x_{p}$, arcsine-transformed values of parameters obtained in flow cytometer approach and age of cows in days. *Bulls that presented a difference higher than $20 \%$ between predicted and observed pregnancy rates

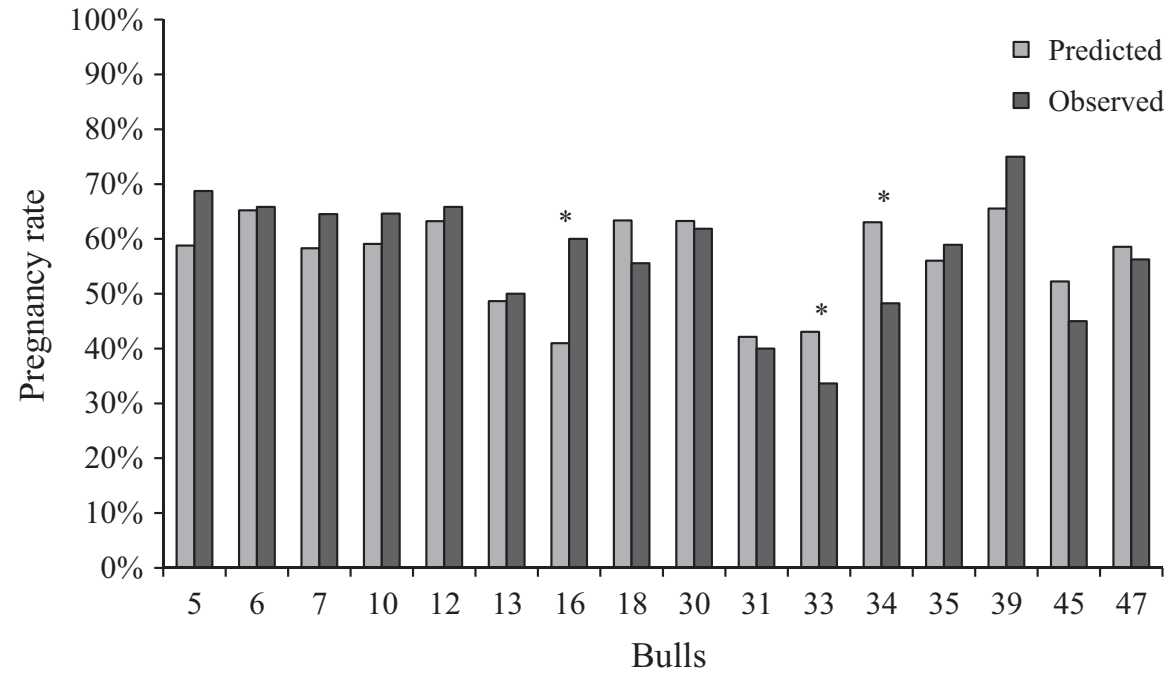

dose (Den Daas, Jong, Lansbergen, \& Wagtendonk-De Leeuw, 1998; Gérard \& Humblot, 1991).

Results of univariate logistic regression of the evaluation of acrosome and plasma membrane integrity (FITC-PSA/PI) variables were conflicting. Proportion of damaged/reacted acrosome was positively while intact acrosome was negatively related to pregnancy. Multivariate logistic regression analysis also indicated that characteristics related to damaged/reacted acrosome showed positive influence on probability of pregnancy. It is noteworthy that cryopreservation process can lead acrosome undergoes to alterations similar to capacitation (Andrade et al., 2011; Cormier \& Bailey, 2003; Green \& Watson, 2001; Neil et al., 2003). These capacitation-like changes may have increased the chances of the sperm population with damaged/reacted acrosome to successfully fertilize the oocyte. It is important to highlight that FITC-PSA is a probe for acrosome reaction that recognizes both partial and complete acrosome-reacted sperm (Jaiswal, Cohen-Dayag, Tur-Kaspa, \& Eisenbach, 1998; Köhn, Mack, Schill, \& Zaneveld, 1997); therefore, we hypothesize that a high sperm population stained for FITC-PSA may increase the probability of pregnancy in cows. Moreover, results of heifer pregnancy were unexpected since damaged plasma and acrosome membranes were related to higher pregnancy rates; however, we highlight that the number of bulls used to analyse heifer pregnancy in this study was lower than for cow pregnancy, so the results of heifer pregnancy should be carefully taken.

Reactive oxygen species (ROS) have an important role on sperm physiology (Aitken, Ryan, Baker, \& McLaughlin, 2004; De Lamirande \& O'Flaherty, 2008; O'Flaherty, Lamirande, \& Gagnon, 2006); however, excessive ROS production or failure in the sperm antioxidants systems may harm sperm functionality (Aitken \& Baker, 2002; Agarwal, Saleh, \& Bedaiwy, 2003). In this study, based on univariate analysis, a high level of $\mathrm{H}_{2} \mathrm{O}_{2}$ even when associated with intact plasma membrane seems to decrease probability of pregnancy in heifers; on the other hand, the level of $\mathrm{H}_{2} \mathrm{O}_{2}$ does not seem to affect probability of pregnancy in cows. Nevertheless, the multivariate analysis for cow pregnancy revealed that high $\mathrm{H}_{2} \mathrm{O}_{2}$ production associated with intact plasma membrane increased probability of

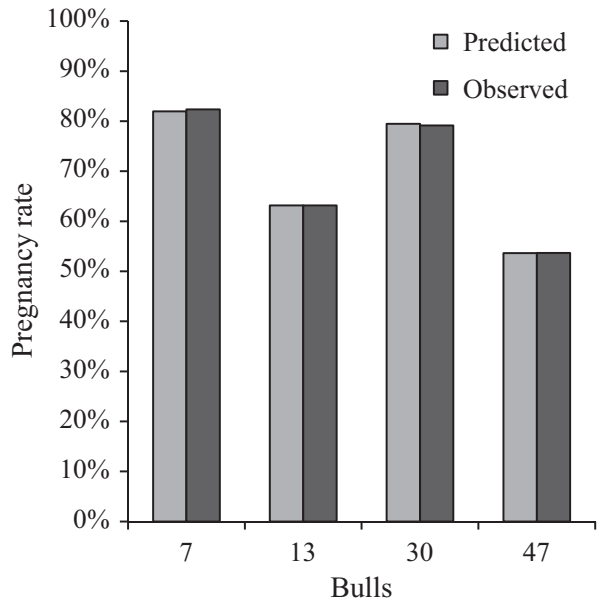

FIGURE 2 Observed and predicted pregnancy rates of bulls used in fixed-time artificial insemination of Nellore heifers. Predicted values were estimated from the general formula $P=\frac{e^{\left(\beta_{0}+\ldots+\beta_{p} x_{p}\right)}}{1+e^{\left(\beta_{0}+\ldots+\beta_{p} x_{p}\right.},}$, where $\beta_{0}$, intercept; $\beta_{\mathrm{p}}$, coefficients estimated by logistic regression for each parameter; and $x_{p}$, arcsine-transformed values of parameters obtained in flow cytometer approach

pregnancy, which may be an unexpected result since it indicates that sperm population with high levels of $\mathrm{H}_{2} \mathrm{O}_{2}$ may increase the chances of pregnancy; however, a physiological increase in ROS occurs in the sperm cell during capacitation process (Aitken et al., 2004; De Lamirande \& O'Flaherty, 2008; O'Flaherty et al., 2006). In fact, sperm with no superoxide ( $\mathrm{SO}^{-}$) or $\mathrm{H}_{2} \mathrm{O}_{2}$ production were negatively related to field fertility in cattle, which could be related to low metabolic activity of the sperm resulting in low pregnancy rates (Morrell, Valeanu, Lundeheim, \& Johannisson, 2018).

This finding associated with results of the acrosome membrane may suggest that a capacitation-like status of sperm right after thawing may enhance the probability of pregnancy in Nellore cows. Nevertheless, capacitation status by CTC staining has showed no correlation with field fertility of Holstein bulls (Gillan et al., 2008), and Thundathil et al. (1999) have reported a positive correlation between proportion of uncapacitated sperm and field fertility 
(non-return rate) in non-synchronized females. However, Gillan, Evans, and Maxwell (1997) pointed out that although the lifespan of capacitated ram sperm was limited, insemination directly into the uterus achieved pregnancy rates comparable to those of fresh semen.

Furthermore, the window of ovulation in synchronized females and the moment of insemination related to ovulation time may interfere in fertility results (Sales et al., 2011). It is known that estradiol benzoate promotes a LH surge $19.6 \mathrm{hr}$ after administration with $\mathrm{LH}$ surge duration of $8.6 \mathrm{hr}$ in Nellore heifers (Sales et al., 2012) and administration of estradiol benzoate on day 8 of FTAI protocol promotes ovulation $59.4 \mathrm{hr}$ after P4 device removal in Nellore cows with $91 \%$ of ovulated cows having their ovulation in a $16 \mathrm{hr}$ of window (48-64 hr) (Ayres et al., 2008). Therefore, we may hypothesize that an ovulation that occurs quite close to artificial insemination in a narrow window of ovulation may favour pre-capacitated sperm to fertilize oocyte.

In conclusion, further investigations regarding the capacitation status of the sperm cell using probes that detect both partial and complete acrosome reaction may clarify the findings reported in this study. Moreover, our findings suggest that the field fertility results of cryopreserved semen in a FTAI programme may be influenced by female fertility, so further analyses should consider the female status (heifer, primiparous or multiparous cows).

\section{ACKNOWLEDGEMENTS}

Authors thank to UNICAFÉ Agrícola S/A, CAPES (Coordenação de Aperfeiçoamento de Pessoal de Nível Superior), CNPq (Conselho Nacional de Desenvolvimento Científico e Tecnológico) and FAPEMIG (Fundação de Amparo à Pesquisa do Estado de Minas Gerais).

\section{CONFLICT OF INTEREST}

Authors declare that there is no conflict of interest.

\section{AUTHOR CONTRIBUTIONS}

DSO was responsible for the conceptualization of the study, data collection, flow cytometer analyses and interpretation of results; JMPF performed the statistical analyses, interpretation of results and paper edition; VEGL participated in the FTAI and data collection; PPM and COS performed the flow cytometer analyses and paper edition; BW, EADM, EPC and SEFG were responsible for interpretation of results and paper edition; and JDG supervised all study and participated of interpretation of results and paper edition.

\section{ORCID}

Jurandy M. Penitente-Filho iD https://orcid. org/0000-0002-8592-4020
Paula P. Maitan iD https://orcid.org/0000-0001-6677-9609

\section{REFERENCES}

Agarwal, A., Saleh, R. A., \& Bedaiwy, M. A. (2003). Role of reactive oxygen species in the pathophysiology of human reproduction. Fertility and Sterility, 79, 829-843. https://doi.org/10.1016/ S0015-0282(02)04948-8

Aitken, R. J., \& Baker, M. A. (2002). Reactive oxygen species generation by human spermatozoa: A continuing enigma. International Journal of Andrology, 25, 191-194. https://doi. org/10.1046/j.1365-2605.2002.03521.x

Aitken, R. J., Ryan, A. L., Baker, M. A., \& McLaughlin, E. (2004). Redox activity associated with the maturation and capacitation of mammalian spermatozoa. Free Radical Biology \& Medicine, 36, 994-1010. https:// doi.org/10.1016/j.freeradbiomed.2004.01.017

Andrade, A. F. C., Zaffalon, F. G., Celeghini, E. C. C., Nascimento, J., Tarragó, O. F. B., Martins, S. M. M. K., ... Arruda, R. P. (2011). Addition of seminal plasma to post-thawing equine semen: What is the effect on sperm cell viability? Reproduction in Domestic Animals, 46, 682686. https://doi.org/10.1111/j.1439-0531.2010.01729.x

Ayres, H., Martins, C. M., Ferreira, R. M., Mello, J. E., Dominguez, J. H., Souza, A. H., ... Baruselli, P. S. (2008). Effect of timing of estradiol benzoate administration upon synchronization of ovulation in suckling Nelore cows (Bos indicus) treated with a progesterone-releasing intravaginal device. Animal Reproduction Science, 109, 77-87. https:// doi.org/10.1016/j.anireprosci.2007.12.001

Bailey, J. L., Robertson, L., \& Buhr, M. M. (1994). Relations among in vivo fertility, computer-analysed motility and $\mathrm{Ca}^{++}$influx in bovine spermatozoa. Canadian Journal of Animal Science, 74, 53-58. https://doi. org/10.4141/cjas94-008

CBRA - Colégio Brasileiro de Reprodução Animal (2013). Manual for andrological exam and evaluation of animal semen (in Portuguese). (3th ed.). Belo Horizonte, Brazil.

Cormier, N., \& Bailey, J. L. (2003). A differential mechanism is involved during heparin-and cryopreservation-induced capacitation of bovine spermatozoa. Biology of Reproduction, 69, 177-185. https://doi. org/10.1095/biolreprod.102.011056

Crespilho, A. M., Papa, F. O., Alberti, K., Siqueira Filho, E. R., Martins Jr, A., Novaes, J. L. C., \& Dell'Aqua, J. A. (2006). Comparative efficiency of two freezing extenders for bovine semen based on sperm motility and membrane integrity (in Portuguese). ARS Veterinária, 22, 229-235.

De Lamirande, E., \& O'Flaherty, C. (2008). Sperm activation: role of reactive oxygen species and kinases. Biochimica Et Biophysica Acta, 1784, 106-115. https://doi.org/10.1016/j.bbapap.2007.08.024

Den Daas, J. H. G., De Jong, G., Lansbergen, L. M. T. E., \& Van Wagtendonk-De Leeuw, A. M. (1998). The relationship between the number of spermatozoa inseminated and the reproductive efficiency of individual dairy bulls. Journal of Dairy Science, 81, 1714-1723. https://doi.org/10.3168/jds.S0022-0302(98)75739-X

Gadea, J. (2005). Sperm factors related to in vitro and in vivo porcine fertility. Theriogenology, 63, 431-444. https://doi.org/10.1016/j. theriogenology.2004.09.023

Gérard, O., \& Humblot, P. (1991). Influence of interactions between semen extender and number of spermatozoa on nonreturn rate estimates of fertility for individual Holstein bulls. Theriogenology, 36(5), 727-736. https://doi.org/10.1016/0093-691X(91)90338-E

Gillan, L., Evans, G., \& Maxwell, W. M. (1997). Capacitation status and fertility of fresh and frozen-thawed ram spermatozoa. Reproduction Fertility and Development, 9, 481-487. https://doi.org/10.1071/ R96046 
Gillan, L., Kroetsch, T., Maxwell, W. M. C., \& Evans, G. (2008) Assessment of in vitro sperm characteristics in relation to fertility in dairy bulls. Animal Reproduction Science, 103, 201-214. https://doi. org/10.1016/j.anireprosci.2006.12.010

Graham, J. K. (2001). Assessment of sperm quality: A flow cytometric approach. Animal Reproduction Science, 68, 239-247. https://doi. org/10.1016/S0378-4320(01)00160-9

Green, C. E., \& Watson, P. F. (2001). Comparison of the capacitationlike state of cooled boar spermatozoa with true capacitation. Reproduction, 122, 889-898. https://doi.org/10.1530/rep.0.1220889

Hosmer, D. W., \& Lemeshow, S. (2000). Applied logistic regression, 2nd ed. New York, NY: Wiley.

Jaiswal, B. S., Cohen-Dayag, A., Tur-Kaspa, I., \& Eisenbach, M. (1998). Sperm capacitation is, after all, a prerequisite for both partial and complete acrosome reaction. FEBS Letters, 427, 309-313. https://doi. org/10.1016/S0014-5793(98)00455-4

Januskauskas, A., Gil, J., Söderquist, L., Hrd, M., Hrd, M. C., Johannisson, A., \& Rodriguez-Martinez, H. (1999). Effect of cooling rates on post-thaw sperm motility, membrane integrity, capacitation status and fertility of dairy bull semen used for artificial insemination in Sweden. Theriogenology, 52, 641-658. https://doi.org/10.1016/ s0093-691X(99)00159-4

Januskauskas, A., Johannisson, A., \& Rodríguez-Martínez, H. (2001). Assessment of sperm quality through fluorometry and sperm chromatin structure assay in relation to field fertility of frozen-thawed semen from Swedish Al bulls. Theriogenology, 55, 947-961. https:// doi.org/10.1016/S0093-691X(01)00456-3

Januskauskas, A., Johannisson, A., \& Rodríguez-Martínez, H. (2003). Subtle membrane changes in cryopreserved bull semen in relation with sperm viability, chromatin structure, and field fertility. Theriogenology, 60, 743-758. https://doi.org/10.1016/ S0093-691X(03)00050-5

Kohn, F. M., Mack, S. R., Schill, W. B., \& Zaneveld, L. J. (1997). Detection of human sperm acrosome reaction: Comparison between methods using double staining, Pisum sativum agglutinin, concanavalin $A$ and transmission electron microscopy. Human Reproduction, 12, 714-721. https://doi.org/10.1093/humrep/12.4.714

Li, Y., Kalo, D., Zeron, Y., \& Roth, Z. (2014). Progressive motility - A potential predictive parameter for semen fertilization capacity in bovines. Zygote, 24, 70-82. https://doi.org/10.1017/S0967199414000720

Macías-García, B., Gonzalez-Fernandez, L., Gallardo-Bolanos, J. M., Peña, F. J., Johannisson, A., \& Morrell, J. M. (2012). Androcoll-E large selects a subset of live stallion spermatozoa capable of producing ROS. Animal Reproduction Science, 132, 74-82. https://doi.org/10.1016/j. anireprosci.2012.03.017

Marquant-Le Guienne, B., Humblot, P., Thibier, M., \& Thibault, C. (1990). Evaluation of bull semen fertility by homologous in vitro fertilization tests. Reproduction Nutrition Development, 30, 259-266. https://doi. org/10.1051/rnd:19900212

Meneghetti, M., Sá Filho, O. G., Peres, R. F. G., Lamb, G. C., \& Vasconcelos, J. L. M. (2009). Fixed-time artificial insemination with estradiol and progesterone for Bos indicus cows I: Basis for development of protocols. Theriogenology, 72, 179-189. https://doi.org/10.1016/j. theriogenology.2009.02.010

Mohanty, T. K., Lone, S. A., Kumaresan, A., Bhakat, M., Kumar, R., Baithalu, R. K., ... Mohanty, A. K. (2018). Sperm dosage and site of insemination in relation to fertility in bovines. Asian Pacific Journal of Reproduction, 7, 1-5. https://doi.org/10.4103/2305-0500.220977

Morado, S., Pereyra, V., Breininger, E., Sara, R., \& Cetica, P. (2015). Study of sperm evaluation parameters to estimate cryopreserved bovine semen fertility. Austin Journal of Veterinary Science and Animal Husbandry, 2, 1005

Morrell, J. M., Valeanu, A. S., Lundeheim, N., \& Johannisson, A. (2018) Sperm quality in frozen beef and dairy bull semen. Acta Veterinaria Scandinavica, 60, 41. https://doi.org/10.1186/s13028-018-0396-2
Neil, D. M., Gadella, B. M., Chaves, M. G., Miragay, M. H., Colenbrande, B. R., \& Agüero, A. (2003). Membrane changes during different stages of a freeze-thaw protocol for equine semen cryopreservation. Theriogenology, 59, 1693-1705. https://doi.org/10.1016/ S0093-691X(02)01231-1

O'Flaherty, C., De Lamirande, E., \& Gagnon, C. (2006). Positive role of reactive oxygen species in mammalian sperm capacitation: Triggering and modulation of phosphorylation events. Free Radicals \& Biology Medicine, 41, 528-540. https://doi.org/10.1016/j. freeradbiomed.2006.04.027

Olds-Clarke, P. (1996). How does poor motility alter sperm fertilizing ability? Journal of Andrology, 17, 183-186. https://doi. org/10.1002/j.1939-4640.1996.tb01773.x

Oliveira, L. Z., Arruda, R. P., Andrade, A. F. C., Celeghini, E. C. C., Santos, R. M., Beletti, M. E., ... Lima, V. F. M. H. (2012). Assessment of field fertility and several in vitro sperm characteristics following the use of different Angus sires in a timed-Al program with suckled Nelore cows. Livestock Science, 146, 38-46. https://doi.org/10.1016/j. livsci.2012.02.018

Oliveira, L. Z., Arruda, R. P., Andrade, A. F. C., Santos, R. M., Beletti, M. E., Peres, R. F. G., ... Hossepian de Lima, V. F. M. (2012). Effect of sequence of insemination after simultaneous thawing of multiple semen straws on conception rate to timed $\mathrm{Al}$ in suckled multiparous Nelore cows. Theriogenology, 78, 1800-1813. https://doi. org/10.1016/j.theriogenology.2012.07.007

Ricci, G., Perticarari, S., Fragonas, E., Giolo, E., Canova, S., \& Pozzobon, C. (2002). Apoptosis in human sperm: Its correlation with semen quality and the presence of leukocytes. Human Reproduction, 17, 26652672. https://doi.org/10.1093/humrep/17.10.2665

Rodríguez-Martínez, H. (2003). Laboratory semen assessment and prediction of fertility: Still utopia? Reproduction in Domestic Animals, 38, 312-318. https://doi.org/10.1046/j.1439-0531.2003.00436.x

Rodríguez-Martínez, H. (2013). Semen evaluation techniques and their relationship with fertility. Animal Reproduction, 10, 148-159. http:// www.cbra.org.br/portal/downloads/publicacoes/animalreproduction/issues/download/v10n3/p148-159\%20(AR631).pdf

Rodríguez-Martínez, H., Larsson, B., Zhang, B. R., \& Söderquist, L. (1997). In vitro assessment of viability and fertilizing capacity of bull spermatozoa. Journal of Reproduction and Development, 43, 1-11. ci.nii.ac.jp/ naid/10027566476/en/

Sales, J. N. S., Carvalho, J. B. P., Crepaldi, G. A., Cipriano, R. S., Jacomini, J. O., Maio, J. R. G., ... Baruselli, P. S. (2012). Effects of two estradiol esters (benzoate and cypionate) on the induction of synchronized ovulations in Bos indicus cows submitted to a timed artificial insemination protocol. Theriogenology, 78, 510-516. https://doi. org/10.1016/j.theriogenology.2012.02.031

Sales, J. N. S., Neves, K. A. L., Souza, A. H., Crepaldi, G. A., Sala, R. V., Fosado, M., ... Baruselli, P. S. (2011). Timing of insemination and fertility in dairy and beef cattle receiving timed artificial insemination using sex-sorted sperm. Theriogenology, 76, 427-435. https://doi. org/10.1016/j.theriogenology.2011.02.019

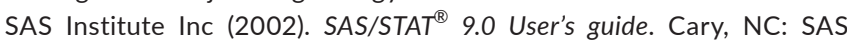
Institute Inc.

Siqueira, J. B., Guimarães, J. D., Costa, E. P., Henry, M., Torres, C. A. A., Silva, M. V. G. B., \& Silveira, T. S. (2007). Relationship between conception rates obtained by using bovine frozen semen and in vitro spermatic evaluation (in Portuguese). Revista Brasileira De Zootecnia, 36, 387-395. https://doi.org/10.1590/S1516-35982007000200016

Stålhammar, E. M., Janson, L., \& Philipsson, J. (1994). The impact of sperm motility on non-return rate in preselected dairy bulls. Reproduction Nutrition Development, 34, 37-45. https://doi.org/10.1051/ rnd:19940104

Sudano, M. J., Crespilho, A. M., Fernandes, C. B., Martins Junior, A., Papa, F. O., Rodrigues, J., ... Landim-Alvarenga, F. C. (2011). Use of Bayesian inference to correlate in vitro embryo production and in vivo fertility 
in Zebu bulls. Veterinary Medicine International, 2011, 1-6. https://doi. org/10.4061/2011/436381

Tartaglione, C. M., \& Ritta, M. N. (2004). Prognostic value of spermatological parameters as predictors of in vitro fertility of frozenthawed bull semen. Theriogenology, 62, 1245-1252. https://doi. org/10.1016/j.theriogenology.2004.01.012

Taş, M., Bacinoglu, S., Cirit, U., Ozdaş, Ö. B., \& Ak, K. (2007). Relationship between bovine fertility and the number of spermatozoa penetrating the cervical mucus within straws. Animal Reproduction Science, 101, 18-27. https://doi.org/10.1016/j.anireprosci.2006.08.020

Thundathil, J., Gil, J., Januskauskas, A., Larsson, B., Soderquist, L., Mapletoft, R., \& Rodriguez-Martinez, H. (1999). Relationship between the proportion of capacitated spermatozoa present in frozen-thawed bull semen and fertility with artificial insemination. International Journal of Andrology, 22, 366-373. https://doi. org/10.1046/j.1365-2605.1999.00194.x

Verberckmoes, S., Van Soom, A., Depauw, I., Dewulf, J., \& de Kruif, A. (2002). Migration of bovine spermatozoa in synthetic medium and its relation to in vivo bull fertility. Theriogenology, 58, 1027-1037. https://doi.org/10.1016/S0093-691X(02)00931-7

Wei, H., \& Fukui, Y. (1999). Effects of bull, sperm type and sperm pretreatment on male pronuclear formation after intracytoplasmic sperm injection in cattle. Reproduction Fertility and Development, 11, 59-65. https://doi.org/10.1071/RD98106
Zhang, B. R., Larsson, B., Lundeheim, N., \& Rodríguez-Martínez, H. (1998). Sperm characteristics and zona pellucida binding in relation to field fertility of frozen-thawed semen from dairy Al bulls. International Journal of Andrology, 21, 207-216. https://doi. org/10.1046/j.1365-2605.1998.00114.x

\section{SUPPORTING INFORMATION}

Additional supporting information may be found online in the Supporting Information section at the end of the article.

How to cite this article: Okano DS, Penitente-Filho JM, Gomez León VE, et al. In vitro evaluation of cryopreserved bovine sperm and its relation to field fertility in fixed-time artificial insemination. Reprod Dom Anim. 2019;54:604-612. https://doi. org/10.1111/rda.13401 